Marketing i Zarządzanie

nr 3 (44) 2016, s. 299-307

DOI: $10.18276 / \mathrm{miz} .2016 .44-27$ ISSN: 2450-775X | http://wnus.edu.pl/pl/miz/

\title{
Katarzyna Caban-Piaskowska
}

\author{
Akademia Sztuk Pięknych w Łodzi \\ Wydział Tkaniny i Ubioru \\ e-mail: k.caban-piaskowska@o2.pl

\section{Design management jako odpowiedź na rozwój nowych segmentów konsumentów}

Kod JEL: M310

Słowa kluczowe: design management, konsument, segmenty rynku, wzornictwo, sztuka Streszczenie. Celem artykułu jest przybliżenie koncepcji design management jako odpowiedzi organizacji na rozwój nowych segmentów konsumentów. Na rynku pojawiła się grupa konsumentów, która szuka oryginalnego wzornictwa, nowych technologii i wielozadaniowości. Nie wystarczy produkować dla nich produkty o bardzo dobrej jakości. Sposobem na realizację ich potrzeb może stać się zastosowanie koncepcji design management $\mathrm{w}$ funkcjonowaniu organizacji. W niniejszej publikacji przedstawiano, w postaci case study, wyniki drugiego wywiadu przeprowadzonego z byłym pracownikiem Desy. Wywiad ten miał na celu uzyskanie informacji, jakie są charakterystyczne cechy nowych rozwijających się segmentów konsumentów, którzy kupują sztukę i sztukę użytkową. Ponadto $\mathrm{w}$ artykule wyjaśniono, jak będzie rozumiane pojęcie design management.

\section{Wprowadzenie}

Niniejszy artykuł jest kontynuacją wcześniejszych publikacji autora dotyczących design management. Tym razem autor za cel przyjął przyjrzenie się nowym segmentom konsumentów, których pojawienie się jest obecnie zauważalne na rynku. Niektóre te segmenty powstały w wyniku ewolucji estetycznej konsumentów (Caban-Piaskowska, 2016a, s. 69-71) oraz nowych wyzwań stawianych przez nich organizacjom (Caban-Piaskowska, 2016b). Reakcją części organizacji na powstanie nowych segmentów jest stosowanie przez nie design management. 
W artykule zilustrowano charakterystykę nowych segmentów konsumentów, korzystając z metody badawczej, jaką jest case study ${ }^{1}$. Analizę przypadku stworzono na podstawie drugiego wywiadu pogłębionego ${ }^{2}$ przeprowadzonego przez autora $\mathrm{z}$ wieloletnim pracownikiem Desy ${ }^{3} \mathrm{w}$ Łodzi, a obecnie kierownikiem Galerii ASP w Łodzi. Celem tego wywiadu było ustalenie, jakie są charakterystyczne cechy nowej grupy konsumentów. Spostrzeżenia zawarte w artykule mają jedynie charakter poglądowy i są przyczynkiem do dalszych badań, które będą prowadzone przez autora $w$ tym obszarze.

\section{Istota design management}

Pojęcie design management jest terminem niejednoznacznym i w zależności od autora, miejsca publikacji, obszaru w którym się pojawia, bywa różnie interpretowany. Autorka pojęcie to będzie rozumiała zgodnie z definicją McBride (2007, s.18): design management jest to całościowe podejście do przedsiębiorstwa, zarówno od strony projektowania oraz wzornictwa, jak i zarządzania, w tym marketingu, finansów, planowania strategicznego oraz działań operacyjnych. Design management interesuje się klientem i jego potrzebami (Best, 2006, s. 11). W wyniku jego stosowania powstałe produkty muszą być m.in. dobre wzorniczo, a nawet być sztuką.

Korzystanie z design management jako strategii w celu odróżnienia produktów oraz bardziej efektywnego zarządzania projektami, projektowania lub budowania wartości marki jest powszechne od 1960 roku (Farr, 1965; Kotler, Rath, 1984; Lorenz, 1987, Acklin 2013). Od tamtej pory naukowcy są pochłonięci definiowaniem tego pojęcia i opisywaniem go z różnych perspektyw (szerzej Caban-Piaskowska 2016a; 2016b). Rolą design management jest tworzenie dóbr i usług, które będą odpowiadały na potrzeby nabywców, a jednocześnie są zgodne z przekonaniami, które reprezentuje organizacja. W celu realizacji tego niezbędne jest m.in. poznanie odbiorców, do których oferta jest kierowana. Opracowany przekaz powinien zawierać informacje zrozumiałe dla klienta. Musi on

\footnotetext{
${ }^{1}$ Metoda analizy przypadków traktowana jest jako jedna z metod badań naukowych. Jest to możliwie dokładny i wielostronny obraz nielicznych przypadków danego zjawiska, celem uzyskania wniosków empirycznych. Pogłębiona, wnikliwa i wielostronna analiza ma w założeniu zastąpić znaczne ilości danych mogące być podstawą do opracowania statystycznego. Niekiedy może zastąpić metodę statystyczną lub metodę eksperymentalną (Pieter, 1967).

${ }^{2}$ Wywiad przeprowadzono w Lodzi 24 maja 2016 r. Był to drugi wywiad przeprowadzony z tym respondentem. Miał on charakter jawny nieformalny i pogłębiony. Ze względu na swobodę zadawania pytań był wywiadem zogniskowanym częściowo ustrukturyzowanym.

${ }^{3}$ To Galeria Sztuki prowadząca sprzedaż dzieł sztuki. Prowadzi działalność handlową i kulturotwórczą, zabezpiecza cenne dzieła sztuki dla zbiorów muzealnych, prowadzi promocję dzieł sztuki współczesnej i jej twórców poprzez prezentacje wystaw w kraju i za granicą. Ma doświadczonych i wykwalifikowanych rzeczoznawców, również biegłych sądowych wykonujących ekspertyzy, oceny i wyceny dzieł sztuki.
} 
uwzględniać poziom wykształcenia konsumenta, do którego jest skierowany produkt, jego wykonywany zawód i sposób życia (Best, 2009, s. 40-42). Projektanci powinni zrozumieć konsumenta, by móc świadomie i podświadomie pojmować jego potrzeby i przekładać je na cechy projektu (Cooper, Pres, 1995).

Od pewnego czasu obserwuje się zjawisko, że design, a raczej „,dobry design" jest jednym z najważniejszych, jeśli nie głównym, wyznacznikiem sukcesu na dzisiejszym konkurencyjnym rynku. Dzięki zwiększonej zdolności producentów do koncentrowania się na konkurowaniu w wymiarach takich jak cena i jakość, działania strategiczne skoncentrowane na dobrym wzornictwie są i nadal będą czynnikiem najbardziej determinującym sukces produktu. Trzeba pamiętać, że o tym decyduje bardzo często umiejętność oceny i zrozumienia gustów konsumentów (Hertenstein, Platt, Veryzer, 2013, s. 8).

W literaturze przedmiotu można znaleźć zestawienia motywów i motywów pokrewnych, którymi kierują się klienci w momencie wyboru produktów designerskich, co przedstawiono w tabeli 1.

Tabela 1

Zestawienie motywów i motywów pokrewnych przy wyborze produktów designerskich

\begin{tabular}{|c|c|c|}
\hline Kategoria respondenta & Motywy & Pokrewne motywy \\
\hline Punkt widzenia klienta & $\begin{array}{l}\text { „Świadomość klienta/do- } \\
\text { świadczenie” } \\
\text { „Odwołanie klienta” } \\
\text { „Głęboka empatia klienta” } \\
\text { „Spełnia i przewyższa oczeki- } \\
\text { wania i wrażenia użytkow- } \\
\text { nika końcowego” } \\
\text { „Zaspokaja potrzeby klien- } \\
\text { tów” } \\
\text { „Zakorzeniony w podejściu } \\
\text { indywidualnym, fizycznym, } \\
\text { emocjonalnym, poznawczym, } \\
\text { kulturowym i potrzebie } \\
\text { ochrony środowiska” } \\
\text { „Doświadczenie użytkownika” } \\
\text { „Uwzględnia wszystkie } \\
\text { aspekty doświadczenia użyt- } \\
\text { kownika” } \\
\text { „Dobry projekt pokazuje do- } \\
\text { świadczenie z produktem” }\end{array}$ & $\begin{array}{l}\text { Zapewnia wartości dla klienta } \\
\text { „Dobra wartość” } \\
\text { „Najlepsza wartość”, } \\
\text { „Koszt/wydajność” } \\
\text { „Uczciwa cena” } \\
\text { „Zapewnia dobrą propozycję } \\
\text { wartości” } \\
\text { „Jakość” } \\
\text { „Dobrze wykonane, trwałe } \\
\text { produkty” } \\
\text { „Cykl życia produktu” } \\
\text { „Wysoka jakość” } \\
\text { „Trwały” } \\
\text { Czyni życie lepszym/prost- } \\
\text { szym } \\
\text { „Głęboka, szczegółowa troska } \\
\text { o tworzenie lepszego życia” } \\
\text { „Ułatwia życie” } \\
\text { „Czyni życie lepszym/szczę- } \\
\text { śliwszy” }\end{array}$ \\
\hline
\end{tabular}

Źródło: na podstawie Hertenstein, Platt, Veryzer, 2013.

Jak wynika z tabeli 1, motywy klientów wybierających produkty designerskie są bardzo zróżnicowane i dotyczą bardzo szerokiego spektrum: zarówno dotychczasowych doświadczeń z produktem, jak i dobrym wzornictwem, ale także z ochroną środowiska. Klienci kierują się też motywami pośrednimi, takimi jak adekwatna cena, ułatwienie życia, trwałość i jakość produktu. 


\section{Rozwój nowych segmentów konsumentów}

Dla zilustrowania zjawiska, jakim jest powstanie nowych segmentów rynku, skorzystano z analizy przypadku, stworzonej, jak już wcześniej zaznaczono, na podstawie pogłębionego wywiadu. Respondentka przez 11 lat sprzedawała dzieła sztuki w łódzkiej Desie, pośredniczyła także pomiędzy konsumentami a artystami, którzy tworzyli m.in. sztukę użytkową. Ponowny wybór respondenta do badania był celowy i wynikał z faktu, że poprzedni wywiad dotyczył potrzeb konsumentów korzystających z usług galerii sztuki, czego kontynuacją logiczną była ta rozmowa. Dotyczyła ona cech charakterystycznych konsumentów i produktów przez nich wybieranych.

Na podstawie przeprowadzonego wywiadu dokonano analizy zebranych wyników i stworzono zestawienie cech oraz korzyści, jakimi kierują się klienci dokonujący zakupów w galerii sztuki (tab. 2).

Tabela 2

Zestawienie cechy produktów w galeriach sztuki z korzyściami dla klienta

\begin{tabular}{|l|l|}
\hline \multicolumn{1}{|c|}{ Cechy produktów } & \multicolumn{1}{c|}{ Korzyści dla klienta } \\
\hline Niepowtarzalność & Poczucie wyjątkowości \\
\hline Produkty sygnowane & Oryginalność, autentyczność danej rzeczy \\
\hline Informacja dodawana o autorze & Kto zrobił daną rzecz \\
\hline Wyjątkowość & Posiadanie rzeczy, której nikt nie ma \\
\hline Dobra jakość & Trwałość rzeczy \\
\hline Polski produkt & Patriotyzm \\
\hline Łódzkie & Patriotyzm lokalny \\
\hline Wyszukane rzeczy & Nowe technologie \\
\hline Wyrafinowane & Świadomość bycia wyjątkowym \\
\hline Eleganckie & Podkreślenie „klasy” posiadacza \\
\hline Modne & Bycie w trendzie \\
\hline Intrygujące - już nie takie bezpieczne & Podkreślenie świadomości artystycznej \\
\hline Ekskluzywne & Podkreślenie statusu społecznego \\
\hline Dopasowane do estetyki miejsca & Podkreślenie poczucia smaku \\
\hline Kreatywne & Wielozadaniowość \\
\hline Uznane nazwiska & Podkreślenie znajomości sztuki \\
\hline
\end{tabular}

Źródło: badania własne.

$\mathrm{Z}$ tabeli 2 wynika, że klientom galerii sztuki zależy na produktach niepowtarzalnych, sygnowanych, zawierających informacje o autorze, wyjątkowych, o dobrej jakości, pochodzących z Polski lub wręcz z Łodzi, które są wyszukanymi rzeczami, wyrafinowanymi i eleganckimi, a zarazem modnymi i intrygującymi, żeby już nie były „bezpieczne”. Ponadto powinny być ekskluzywne, dopasowane do estetyki miejsca, pokazujące kreatywność, a przy okazji oryginalne i autentyczne. Korzyścią, jaka wynika z ich posiadania, jest świadomość, kto zrobił daną rzecz, najlepiej jeżeli zostały stworzone przez uznane nazwiska, co daje ich wła- 
ścicielom poczucie posiadania wyjątkowego przedmiotu i dzięki temu bycia wyjątkowym. Ponadto korzyścią dla klienta jest posiadanie rzeczy, której nikt inny nie ma, która jest trwała, podkreślająca „klasę” posiadacza, jego świadomość artystyczną, status społeczny, poczucie smaku, posiadaną wiedzę o sztuce, ale także jego patriotyzm, w tym także ten lokalny oraz bycie modnym.

Innym obszarem badanym w trakcie wywiadu były cechy klienta charakterystyczne dla klientów galerii sztuki. Cechy te podzielono na kilka grup i przedstawiono w tabeli 3 . W tabeli zestawiono tylko wybrane czynniki. Nie zostały uwzględnione niektóre rodzaje czynników, kategorie oraz cechy, gdyż nie występują one w opisywanej grupie konsumentów lub są nieistotne w niniejszym badaniu.

Tabela 3

Zestawienie cechy charakterystycznych dla klientów galerii sztuki

\begin{tabular}{|c|c|c|c|}
\hline $\begin{array}{l}\text { Rodzaj } \\
\text { czynnika }\end{array}$ & Kategoria & $\begin{array}{c}\text { Cechy } \\
\text { wyróżniające }\end{array}$ & Charakterystyka zakupów \\
\hline \multirow{9}{*}{$\begin{array}{l}\text { Czynniki de- } \\
\text { mograficzne }\end{array}$} & \multirow{3}{*}{ wiek } & $30-35$ & $\begin{array}{l}\text { rzeczy kupowane dla kogoś - na prezenty: ślubne, } \\
\text { okrągłe rocznice urodzin; są to osoby charakteryzujące } \\
\text { się absolutną nonszalancją, jeżeli chodzi o świado- } \\
\text { mość sztuki }\end{array}$ \\
\hline & & $45-50$ & $\begin{array}{l}\text { osoby, które przez lata odwiedzały galerie i teraz szu- } \\
\text { kają czegoś dla siebie, mają kolejny dom, przychodzą } \\
\text { z projektantem albo kupują dla kogoś na prezenty } \\
\text { imieninowe i rocznice; najbardziej poszukiwane są } \\
\text { grafiki, a jeżeli ktoś decyduje się na zakup obrazu, to } \\
\text { musi on mieć format, który da się schować do walizki }\end{array}$ \\
\hline & & $55+$ & $\begin{array}{l}\text { kupują prezenty dla dzieci i wnuków; są to podarunki } \\
\text { ślubne oraz rocznicowe; rzadko kupują rzeczy dla sie- } \\
\text { bie; bardzo często kupują tradycyjne obrazy z moty- } \\
\text { wem kwiatów i krajobrazy; dodatkowym wymogiem } \\
\text { jest fakt, żeby obraz zmieścił się do auta }\end{array}$ \\
\hline & \multirow{3}{*}{ płeć } & $\begin{array}{c}\text { zakupy } \\
\text { w parach }\end{array}$ & $\begin{array}{l}\text { jest to dominująca grupa klientów, która dość długo } \\
\text { podejmuje decyzje o zakupie }\end{array}$ \\
\hline & & kobiety & $\begin{array}{l}\text { jest to mniej liczna grupa klientów, którzy decydują } \\
\text { się bardzo długo i robią zakupy gremialnie }\end{array}$ \\
\hline & & mężczyźni & $\begin{array}{l}\text { prezenty kupowane zwykle dla gości odwiedzających } \\
\text { instytucje; zakupy te charakteryzują się szybkim pro- } \\
\text { cesem decyzyjnym }\end{array}$ \\
\hline & \multirow{3}{*}{ narodowość } & Polacy & podstawowa grupa klientów \\
\hline & & $\begin{array}{l}\text { małżeństwa } \\
\text { mieszane }\end{array}$ & częsta grupa klientów \\
\hline & & obcokrajowcy & $\begin{array}{l}\text { rzadka, ale pojawiająca się grupa, która kupuje pa- } \\
\text { miątki przedstawiające Łódź }\end{array}$ \\
\hline \multirow{3}{*}{$\begin{array}{l}\text { Czynniki } \\
\text { psychogra- } \\
\text { ficzne }\end{array}$} & $\begin{array}{l}\text { zaintereso- } \\
\text { wania }\end{array}$ & $\begin{array}{l}\text { związane ze } \\
\text { sztuką }\end{array}$ & $\begin{array}{l}\text { konsumenci, którzy uczestniczą w wydarzeniach kul- } \\
\text { turalnych, interesują się designem, chodzą na wystawy } \\
\text { w celu poszerzenia swojej wiedzy }\end{array}$ \\
\hline & styl życia & $\begin{array}{l}\text { urządzają } \\
\text { nowe miesz- } \\
\text { kania }\end{array}$ & $\begin{array}{l}\text { grupa ludzi, która urządza nowe mieszkania, korzysta- } \\
\text { jąc z usług projektantów }\end{array}$ \\
\hline & $\begin{array}{l}\text { wykształce- } \\
\text { nie }\end{array}$ & wyższe & główna grupa odbiorców \\
\hline
\end{tabular}




\begin{tabular}{|c|c|c|c|}
\hline \multirow{9}{*}{$\begin{array}{l}\text { Czynniki } \\
\text { społeczno- } \\
\text { ekonomiczne }\end{array}$} & $\begin{array}{l}\text { sytuacja fi- } \\
\text { nansowa }\end{array}$ & $\begin{array}{l}\text { dość zamożni, } \\
\text { ale nie bogaci } \\
\quad-\text { „lepsza } \\
\text { klasa średnia” }\end{array}$ & $\begin{array}{l}\text { dominująca grupa odbiorców, która jest nauczona ob- } \\
\text { cowania ze sztuką }\end{array}$ \\
\hline & \multirow{5}{*}{$\begin{array}{l}\text { wykony- } \\
\text { wany zawód }\end{array}$} & farmaceuci & $\begin{array}{l}\text { dominująca grupa odbiorców, która kupuje trochę } \\
\text { droższe rzeczy niż przedstawiciele innych zawodów, } \\
\text { mają oni świadomość artystyczną }\end{array}$ \\
\hline & & $\begin{array}{l}\text { profesorzy } \\
\text { wizytujący } \\
\text { uczelnie }\end{array}$ & $\begin{array}{l}\text { duża grupa odbiorców, kupująca najdroższe rzeczy } \\
\text { w porównaniu } \mathrm{z} \text { innymi grupami zawodowymi }\end{array}$ \\
\hline & & lekarze & $\begin{array}{l}\text { głównie dla nich kupowane są prezenty; w przypadku } \\
\text { kupujących dla tej grupy istotny jest fakt, że dokonują } \\
\text { zakupu w galerii sztuki; w związku z tym prezenty po- } \\
\text { winny być zapakowane w sposób, który jednoznacznie } \\
\text { sugeruje; gdzie był on dokonany }\end{array}$ \\
\hline & & prawnicy & kupują sobie, ale także na prezenty \\
\hline & & $\begin{array}{l}\text { osoby prowa- } \\
\text { dzące własny } \\
\text { biznes }\end{array}$ & $\begin{array}{l}\text { rzeczy kupowane głównie jako wystrój biura, mają od- } \\
\text { zwierciedlać charakter miejsca i jego wyjątkowość }\end{array}$ \\
\hline & \multirow{3}{*}{$\begin{array}{l}\text { położenie } \\
\text { geogra- } \\
\text { ficzne }\end{array}$} & łodzianie & dominująca grupa klientów \\
\hline & & warszawiacy & $\begin{array}{l}\text { druga co do wielkości grupa konsumentów kupująca } \\
\text { droższe rzeczy niż inni }\end{array}$ \\
\hline & & $\begin{array}{l}\text { Polacy miesz- } \\
\text { kający na } \\
\text { emigracji }\end{array}$ & $\begin{array}{l}\text { klienci występujący w mniejszości, kupują rzeczy dla } \\
\text { siebie i dla rodziców }\end{array}$ \\
\hline
\end{tabular}

Źródło: badania własne.

Jak wynika z tabeli 3, wyróżnione grupy konsumentów różnią się między sobą, ich decyzjom zakupowym towarzyszą różne przyzwyczajenia, kierują się różnymi motywami zakupowymi; część konsumentów kupuje rzeczy dla siebie, część jest nimi obdarowywana. Cechami, które łączą wszystkie grupy konsumenckie, są: wykształcenie wyższe, stan posiadania, gdyż są to osoby dość zamożne, jednak nie bogate, ich zainteresowania są związane ze sztuką, nawet jeżeli ich wiedza na razie jest znikoma.

W wyniku przeprowadzonego wywiadu zostały wyodrębnione cztery dominujące grupy konsumentów (tab. 4). W zestawieniu nowych segmentów konsumentów nie zostali uwzględnieni kolekcjonerzy, ponieważ, co było dość zadziwiające dla autora, stanowią oni mniejszość wśród kupujących w galerii sztuki i w związku z tym nie można było uznać ich za istotny segment konsumentów.

Cechami charakterystycznymi segmentu „Lofty” są: wiek 40-50 lat, wyższe wykształcenie, zakup produktów designerskich. Produkty kupują dla siebie, a ich proces decyzyjny często odbywa się w parach. Produkty muszą pasować do wnętrza, które najczęściej jest urządzane przez projektanta.

Segment „Wesołe obrazy” to osoby w wieku 40-50 oraz 55+, farmaceuci i osoby prowadzące własną działalność. Zakupów dokonują ze snobizmu, w celu pokazania się. Szukają twórców z wyrobionymi nazwiskami, sztuki miłej w odbiorze, pasującej do wszystkiego. 
Tabela 4

Nowe segmenty konsumentów korzystających z galerii sztuki

\begin{tabular}{|l|l|}
\hline Nazwa segmentu & \multicolumn{1}{|c|}{ Motyw zakupu i charakterystyka odbiorcy } \\
\hline Lofty & $\begin{array}{l}\text { urządzanie nowego loftu lub apartamentu, często z wykorzystaniem } \\
\text { z usług projektanta, który dobiera rzeczy do wnętrz; często najpierw na- } \\
\text { stępuje wypożyczenie danej rzeczy w celu sprawdzenia, czy pasuje do } \\
\text { wnętrza }\end{array}$ \\
\hline Wesołe obrazy & $\begin{array}{l}\text { snobizm, chęć pokazania się, kupowane są rzeczy twórców z wyrobio- } \\
\text { nymi nazwiskami; sztuka pasująca do wszystkiego, także do kapy na ka- } \\
\text { napie, miła w odbiorze, ale tylko „wesołe obrazy”; klientami najczęściej } \\
\text { są kobiety, właścicielki hurtowni aptek }\end{array}$ \\
\hline Ładne & zakupy, które mają się podobać osobom obdarowanym - prezenty \\
\hline Coś z galerii & $\begin{array}{l}\text { sztuka nowoczesna dla siebie i na prezenty, sygnowana przez autorów, } \\
\text { nie masowa, oryginalne wzornictwo }\end{array}$ \\
\hline
\end{tabular}

Źródło: badania własne.

Kolejny segment konsumentów, nazwanych przez respondentkę „Ładne”, to osoby w wieku 30-35 lat, które kupują sztukę na prezent, są to pary lub mężczyźni, którzy zwykle nie znają się na sztuce, Polacy lub pary mieszane.

Ostatni opisywany segment konsumentów, „Coś z galerii”, grupa, która ma najwyższą świadomość artystyczną, to ludzie w wieku 40-50 lat, prawnicy i osoby prowadzące własną działalność, ale także profesorzy wizytujący, kupują produkty sygnowane, nie masowe, są to łodzianie i warszawiacy.

Przedstawione cztery grupy konsumentów są charakterystyczne dla klientów galerii sztuki. Można zauważyć, że przedstawiają one cechy charakterystyczne dla konsumentów korzystających z produktów designerskich (por. tab. 1). Ponadto cechy konsumentów galerii sztuki są tożsame $\mathrm{z}$ cechami osób kupujących produkty tworzone przy pomocy design management, w związku z czym można pokusić się o stwierdzenie, że odpowiedzią organizacji na rozwój nowych segmentów konsumentów jest stosowanie koncepcji design management.

\section{Podsumowanie}

Na podstawie przeprowadzonych badań nie można uogólniać wyników. Głównym wnioskiem jest stwierdzenie, że istnieją cztery główne segmenty konsumentów, którzy kupują w galeriach sztuki. Cechy tych grup konsumenckich przekładają się bezpośrednio na klientów korzystających z produktów tworzonych w oparciu o design management. Są to osoby z wykształceniem wyższym, ich sytuacja finansowa jest bardzo dobra, to osoby dość zamożne, ale nie bogate. Sztuka jest kupowana dla siebie lub na prezenty, powinna być sygnowana. Bardzo często są to rzeczy kupowane do nowych wnętrz, takich jak lofty i apartamenty, mają pasować do konkretnego wnętrza, często pomagają w tym architekci wnętrz. Odpowiedzią na powstanie tych nowych segmentów rynku jest stosowanie koncepcji design management $\mathrm{w}$ funkcjonowaniu organizacji. Artykuł jest 
punktem wyjścia do dalszych badań w tym obszarze. Założeniem autora jest stworzenie pełnych badań, które będą pokazywały zastosowanie design management $\mathrm{w}$ różnych ujęciach.

\section{Bibliografia}

Acklin, C. (2013). Design management absorption model: a framework to describe and measure the absorption process of design knowledge by SMEs with little or no prior design experience. Creativity And Innovation Management, 22 (2), 147-160.

Best, K. (2006). Design management - managing design strategy. Process and implementation. Lausanne: AVA Publishing.

Best, K. (2009). Design management. Zarzadzanie strategia, procesem projektowym i wdrażaniem nowego produktu. Warszawa: Wydawnictwo Naukowe PWN.

Caban-Piaskowska, K. (2016a). Design management as the effect of evolution of consumers' aesthetics. The West East Institute, 69-71.

Caban-Piaskowska, K. (2016b). Design management jako odpowiedź na wyzwania stawiane przez konsumentów przyszłości. Studia i Prace WNEiZ, w druku.

Cooper, R., Press, M. (1995). The design agenda: a guide to successful design management. Chichester: John Wiley \& Sons.

Farr, M. (1965). Design management. Why is it needed now? Design Journal, 200, 38-39.

Hertenstein, J., Platt, M., Veryzer R. (2013). What is „good design”? An investigation of the complexity and structure of design. Design Management Journal, 8 (1), 8-21.

Kotler, Ph., Rath, G.A. (1984). Design: a powerful but neglected strategic tool. Journal of Business Strategy, 5, 16-21.

Lorenz, C. (1987). The design dimension: the new competitive weapon for business. Oxford: Blackwell Publisher.

McBride, M. (2007). Design management: future forward. Design Management Review, 18, 17-22.

Pieter, J., (1967). Ogólna metodologia pracy naukowej. Wrocław: Ossolineum.

\section{Design Management as a Response to the Development of New Segments of Consumers}

Keywords: design management, consumer, market segments, design, art

Summary. The article aims to present the idea of design management as the answer of an organization to the development of new consumer segments. There is a new group of consumers on the market who seek original design, new technologies and multifunctionality. It is not enough to produce high quality products for them. The implementation of the idea of design management in an organization can become a way to fulfil their needs. The article presents, in a form of a case study, the results of the second interview conducted with an employee of Desa. The interview's purpose was to obtain knowledge about the characteristic features of the new developing consumer segments who buy applied arts. What is more, the article explains how the issue of design management is understood. 


\section{Cytowanie}

Caban-Piaskowska, K. (2016). Design management jako odpowiedź na rozwój nowych segmentów konsumentów. Marketing i Zarzązanie, 3 (44), 299-307. 